\title{
The effects of the ethanolic extract of mahogany seeds (Swietenia macrophylla King) on the renal function of streptozotocin-induced diabetic rats
}

\author{
Lukman La Basy ${ }^{1, *}$, Sri Lestari S R ${ }^{2}$, Sri Kadarsih ${ }^{2}$ \\ ${ }^{1}$ Sekolah Tinggi Ilmu Kesehatan, Maluku Husada, Moluccas, Maluku, \\ ${ }^{2}$ Department of Physiology, Universitas Gadjah Mada, Yogyakarta, Indonesia
}

DOI: http://dx.doi.org/10.19106/JMedSci004702201501

\begin{abstract}
ABSRACT
Diabetes-associated oxidative stress causes glomerular hypertrophy, decrease of glomerular filtration rate and inhibits cell proliferation that lead to the decrease of renal function as indiated by the increase of serum creatinine level and the presence of protein in urine. Mahogany seed (Swietenia macrophylla King) has been proven to have antidiabetic activity. This study was conducted to evaluate the effect of the ethanolic extract of mahogany seeds on the renal function of streptozotocin-induced diabetic rats. Six normal rats as control (Group I) and 24 diabetic rats were used in this study. The diabetic rats were randomized allocated into four groups with six rats in each group. Group II was considered as diabetic rats control and received aquadest. Group III-V were considered as extract administered diabetic group and received ethanolic extract of $S$. macrophylla seed for 21 days at a dose of 50, 100 and $200 \mathrm{mg} / \mathrm{kg} \mathrm{BW}$, respectively. Serum malondialdehyde (MDA), serum creatinine, and urine protein levels were monitored, before and after the ethanolic extract of $S$. macrophylla seed administration. Serum MDA, serum creatinine and urine protein levels of all rats after STZ induction (Group II-V) were significantly higher than without STZ induction $(p<0.05)$. A significant decrease in the serum MDA and serum creatinine as well as urine protein levels were observed after the treatment with ethanolic extract of $S$. macrophylla seed compared to before treatment $(p<0.05)$. In conclusion, the ethanolic extract of $S$. macrophylla seed is able to correct renal dysfunction of streptozotocin-induced diabetic rats.
\end{abstract}

\section{ABSTRAK}

Stres oksidatif akibat diabetes dapat menyebabkan hipertropi glomerulus, penurunan kecepatan filtrasi glomerulus dan penghambatan proliferasi sel yang berakibat terjadinya penurunan fungsi ginjal sebagaimana ditunjukkan dengan penurunan kreatinin serum dan adanya urin protein. Biji mahoni (Swietenia macrophylla King) terbukti mempunyai aktivitas antidiabetes. Penelitian ini dilakuan untuk mengkaji efek ekstrak etanol biji mahoni pada fungsi ginjal tikus diabetes yang diinduksi streptozotosin. Enam tikus normal sebagai kontrol (Kelompok I) dan 24 tikus diabetes digunakan dalam penelitian. Tikus diabetes dibagi menjadi 4 kelompok secara random dengan 6 ekor tikus masing-masing kelompok. Kelompok II sebagai kontrol tikus diabetes menerima air suling. Kelompok III-V sebagai

Corresponding author: Lukman.apt@gmail.com 
kelompok perlakuan menerima ekstrak etanol biji mahoni (S. macrophylla King) selama 21 hari dengan dosis berturut-turut 50, 100 dan $200 \mathrm{mg} / \mathrm{kg} \mathrm{BB}$. Kadar malodehaldehid (MDA) serum, kreatinin serum dan protein urin diukur sebelum dan sesudah pemberian ekstrak etanol biji mahoni. Kadar MDA serum, kreatinin serum dan protein urin pada semua tikus setelah induksi STZ (Group II-V) lebih tinggi secara bermakna dibandingkan tanpa induksi STZ $(p<0,05)$. Penurunan secara nyata terhadap kadar MDA serum, kreatinin serum dan protein urin dijumpai setelah pemberian ekstrak etanol $S$. macrophylla King dibandingkan sebelum pemberian $(p<0,05)$. Kesimpulan, ekstrak etanol biji mahoni dapat memperbaiki disfungsi ginjal tikus diabetes yang diinduksi streptozotosin.

Key words : hyperglycemia, Swietenia macrophylla King, serum creatinine, MDA, urine protein

\section{INTRODUCTION}

Diabetes mellitus (DM) is a metabolic disease characterized by hyperglycemia due to a decrease in insulin secretion, insulin action, or both. ${ }^{1}$ Complications of diabetes due to hyperglycemia includes macrovascular (coronary artery disease, peripheral arterial disease, and stroke) and microvascular (diabetic nephropathy, neuropathy, and retinopathy) dysfunctions. ${ }^{2}$ Oxidative stress caused by hyperglycemia plays an important role in those macrovascular and microvascular complications of DM.,3 Oxidative stress occurs as result of the increase of peroxidation product as a mediator of tissue damage and leads to the activation of pathogenesis complication pathways of DM. ${ }^{3}$

Malondialdehyde (MDA) is a product of lipid peroxidation due to the increase of reactive oxygen species (ROS) level on the oxidative stress conditions. Plasma MDA is frequently used as biomarker for oxidative stress. In diabetics condition, plasma MDA level increases due to the decrease of antioxidant level and leads the early systemic complications of diabetes as expressed by the increased AGEs, protein, lipid serum, lymphocytes, and urine of diabetic patients. ${ }^{4,5}$ Moreover, oxidative stress causes glomerular hypertrophy, decrease of glomerular filtration rate and inhibits cell proliferation that lead to the decrease of renal function as indiated by the increase of serum creatinine level and the presence of protein in urine. ${ }^{5-7}$

Previous studies showed the benefits and potential of some medicinal plants in dealing with oxidative stress in both the treatment of diabetes and its complication. ${ }^{8}$ Mahogany (Swietenia macrophylla King) was proven to have antidiabetic activity. The aqueousmethanolic extract of the mahogany seed induces the pancreatic $\beta$ cells regeneration and increases the insulin production due to its antioxidant activity through glucose autooxidant and protein glycation pathways. ${ }^{9}$ In addition, the alcoholic mahogany seed extract stimulates the glucokinase enzyme, a major catalyst in the posporilation of glucose, in lowering blood glucose levels. ${ }^{10}$

Streptozotocin (STZ) is widely used to induce experimental both insulin-dependent and non-insulin-dependent diabetes mellitus in animals, respectively. The mechanism of STZ action in $\beta$ cells has been intensively investigated and is well understood. ${ }^{11}$ Streptozotocin entering the B cell via a glucose transporter (GLUT2) causes DNA damage due to alkylation of DNA. The DNA damage induces activation of poly ADP-ribosylation leads to depletion of cellular $\mathrm{NAD}^{+}$and ATP 
resulting in the formation of ROS. Moreover, STZ liberates toxic amounts of nitric oxide that inhibits aconitase activity and participates in DNA damage. As a result of the STZ action, $\beta$ cells undergo the destruction by necrosis. ${ }^{12,13}$

The present study was designed to evaluate the effects of the ethanolic extract of mahogany seeds ( $S$. macrophylla King) on the renal function of streptozotocin-induced diabetic rats. The renal function was expressed by serum creatinine and urinary protein levels. Furthermore, the plasma MDA level after the ethanolic administration was also evaluated.

\section{MATERIALS AND METHODS}

\section{Ethanolic extract preparation}

The S. macrophylla King seeds were collected in The Bogor Botanical Gardens, Indonesia and identified by a botanist in The Faculty of Pharmacy, Universitas Gadjah Mada Yogyakarta. The seeds were separated from the fruits, dried under open air conditions and powdered using a blender. The powdered seeds were extracted with ethanol by the ethanol method for three days. The extract was filtered through Whatman filter and the filtrate was collected and concentrated in a rotary evaporator at $40{ }^{\circ} \mathrm{C}$. The concentrated extract was dried under open air and stored under refrigeration until further use.

\section{Induction of diabetes by streptozotocin}

Wistar strain male albino rats, 6-8 weeks of age, weighing from 180 to $200 \mathrm{~g}$ were selected for this study. All rats were acclimated for a period of 7 days in our laboratory condition prior to the study. Rats were housed at room temperature under 12 hours cycles of dark and light and were fed standard food and water $a d$ libitum. Induction of diabetes in the rats were performed by a single intraperitoneal injection of STZ at dose of $60 \mathrm{mg} / \mathrm{kg} \mathrm{BW}$ in $0.1 \mathrm{~mL}$ of freshly citrate buffer $(0.01 \mathrm{M}$ and $\mathrm{pH}=4.5)$. The day of STZ injection was designated as day 0 (D-0). Development of diabetes was confirmed by measuring blood glucose level four days after STZ injection (D-4). Rats with the blood glucose level higher than 200 $\mathrm{mg} / \mathrm{dL}$ were considered to be diabetic. The diabetic rats were then selected for the study. This study has been approved by Medical and Health Research Ethics Committee, Faculty of Medecine, Universitas Gadjah Mada, Yogyakarta.

\section{Animal treatment}

Six normal rats and 24 diabetic rats were used in this study. The normal rats were considered as non diabetic rats control and received aquadest (Group I). The diabetic rats were randomized allocated into four groups with six rats in each group. Group II was considered as diabetic rats control and received aquadest. Group III-V were considered as extract administered diabetic group and received ethanolic extract of $S$. macrophylla seed at a dose of 50,100, and $200 \mathrm{mg} / \mathrm{kg} \mathrm{BW}$, respectively. The ethanolic extract was administered one time per day at 08.00 AM started from day 4 and continued for next 21 days. Blood glucose level was measured and monitored on day 0 (D-0), 4 (D-4), 18 (D-18) and 25 (D-25), respectively. In addition, serum creatinine, serum MDA and urine protein levels were also monitored, however only on day 4 (D-4) and 25 (D-25), respectively.

\section{Biochemical analysis}

A volume of $2 \mathrm{~mL}$ orbital sinus blood sample was collected from each study rat and assayed by standard methods for estimation of blood glucose, serum creatinine and MDA levels. The blood glucose level was measured 
by glucose oxidase peroxidase (GOP-PAP) method.14 The serum creatinine level was measured by Jaffe method $^{15}$, MDA level was measured by TBARS metod ${ }^{16}$ and urine protein level was measured by colorimetric test pyrogallon red metod. ${ }^{17}$ All spectrophotometric measurements were carried out in a DR6000 UV-Visible spectrophotometer (Hach-US).

\section{Statistical analysis}

All the results were expressed as mean \pm standard deviation (SD) for six animals in each group. Statistical comparisons were performed using one way analysis of variance (ANOVA) followed by Post Hoc Tests Least Significant Difference (LSD). p-values of less than 0.05 were considered to indicate statistical significance.

\section{RESULTS}

\section{The effect of ethanolic extract of mahogany seeds on blood glucose level}

Blood glucose level of all rats in all groups before STZ induction were in normal level (TABLE 1). A significant increase in the level of blood glucose level was observed four days after STZ induction (D-4) when compared to before STZ induction $(p<0.05)$. All rats on
Group II-V had the blood glucose level higher than $200 \mathrm{mg} / \mathrm{dL}(\mathrm{p}>0.05)$. Furthermore, a significant decrease in the level of blood glucose level was observed 14 (D-18) as well as 21 (D-25) days after the treatment with ethanolic extract of $S$. macrophylla seed (Group III-V) $(\mathrm{p}<0.05)$. The blood glucose levels in diabetic rats of the Group III-V were in normal level $(<200 \mathrm{mg} / \mathrm{mL})$ on D-18 and D-25. In contrast, the blood glucose level in diabetic rats of Group II (without treatment with the ethanolic extract) remained higher on D-18 and D-25 ( $p>0.05)$ (TABLE 1).

\section{The effect of ethanolic extract of maho- gany seeds on serum MDA level}

Serum MDA level of all rats four days after STZ induction (Group II-V) were significantly higher than without STZ induction ( $p<$ 0.05) (TABLE 2). A significant decrease in the serum MDA level was observed 21 (D25) days after the treatment with ethanolic extract of S. macrophylla seed (Group III-V) compared to before treatment (D-4) (p < $0.05)$. No significant difference in the serum MDA level was observed on D-4 compared to on D-25 in Group II ( $p>0.05)$ (TABLE 2).

TABLE 1. Effect of ethanolic extract of $S$. macrophylla seed on blood glucose levels $(\mathrm{mg} / \mathrm{dL})$ in diabetic rats

\begin{tabular}{clcccc}
\hline \multirow{2}{*}{ Group } & \multicolumn{2}{c}{ Treatment } & \multicolumn{4}{c}{ Mean \pm Standard Deviation } \\
\cline { 3 - 6 } & & D-0 & D-4 & D-18 & D-25 \\
\hline I & Aquadest & $82.42 \pm 5.24$ & $77.75 \pm 3.09$ & $82.73 \pm 5.04$ & $84.90 \pm 6.75$ \\
II & STZ + aquadest & $74.83 \pm 1.81$ & $230.10 \pm 2.99$ & $233.48 \pm 6.06$ & $234.15 \pm 3.23$ \\
III & STZ + extract 50 mg & $74.12 \pm 2.55$ & $227.66 \pm 8.69$ & $183.28 \pm 13.06$ & $145.43 \pm 5.83$ \\
IV & STZ + extract 100 mg & $75.76 \pm 2.45$ & $230.45 \pm 3.74$ & $146.07 \pm 14.81$ & $124.57 \pm 2.06$ \\
V & STZ + extract 200 mg & $75.31 \pm 3.28$ & $230.86 \pm 4.30$ & $127.01 \pm 23.55$ & $102.92 \pm 4.42$ \\
\hline
\end{tabular}

D-0: day on STZ induction; D-4: 4 days after STZ induction; D-18: 14 days after administration of ethaolic extract; D-25: 21 days after administration of ethanolic extract. 
Lukman La Basy et al., The effects of the ethanolic extract of mahogany seeds (Swietenia macrophylla King) on the renal function of streptozotocin-induced diabetic rats

TABLE 2. Effect of ethanolic extract of S. macrophylla seed on serum MDA level (mg/dL) in diabetic rats

\begin{tabular}{clcc}
\hline \multirow{2}{*}{ Group } & Treatment & \multicolumn{2}{c}{ Mean \pm Deviation Standard } \\
\cline { 3 - 4 } & & $2.27 \pm 0.62$ & D-25 \\
\hline I & Aquadest & $8.72 \pm 0.64$ & $8.31 \pm 0.13$ \\
II & STZ + aquadest & $8.31 \pm 0.77$ & $5.23 \pm 0.53$ \\
III & STZ + extract 50 mg & $8.08 \pm 0.47$ & $3.71 \pm 0.42$ \\
IV & STZ + extract 100 mg & $8.22 \pm 0.37$ & $2.56 \pm 0.35$ \\
V & STZ + extract 200 mg & \\
\hline
\end{tabular}

D-4: 4 days after STZ induction; D-25: 21 days after administration of ethanolic extract.

\section{The effect of ethanolic extract of mahogany seeds on serum creatinine level}

Serum creatinine level of all rats four days after STZ induction (Group II-V) were significantly higher than without STZ induction $(\mathrm{p}<0.05)($ TABLE 3$)$. A significant decrease in the serum creatinine level was observed 21 (D-25) days after the treatment with ethanolic extract of S. macrophylla seed (Group III-V) compared to before treatment $(\mathrm{D}-4)(\mathrm{p}<0.05)$. No significant difference in the serum creatinine level was observed on D-4 compared to on D-25 in Group II ( $p>$ 0.05) (TABLE 3).

TABLE 3. Effect of ethanolic extract of S. macrophylla seed on serum creatinine level $(\mathrm{mg} / \mathrm{dL})$ in diabetic rats

\begin{tabular}{clcc}
\hline \multirow{2}{*}{ Group } & Treatment & \multicolumn{2}{c}{ Mean \pm Deviation Standard } \\
\cline { 3 - 4 } & & D-4 & D-25 \\
\hline I & Aquadest & $1.26 \pm 0.33$ & $0.67 \pm 0.04$ \\
II & STZ + aquadest & $3.49 \pm 0.15$ & $3.90 \pm 0.23$ \\
III & STZ + extract $50 \mathrm{mg}$ & $3.50 \pm 0.26$ & $2.12 \pm 0.22$ \\
IV & STZ + extract $100 \mathrm{mg}$ & $3.62 \pm 0.18$ & $1.37 \pm 0.34$ \\
V & STZ + extract $200 \mathrm{mg}$ & $3.56 \pm 0.14$ & $0.68 \pm 0.09$ \\
\hline
\end{tabular}

D-4: 4 days after STZ induction; D-25: 21 days after administration of ethanolic extract.

Urine protein level of all rats four days after STZ induction (Group II-V) were significantly higher than without STZ induction $(\mathrm{p}<0.05)$ (TABLE 3). A significant decrease in the urine protein level was observed 21 (D-25) days after the treatment with ethanolic extract of
S. macrophylla seed (Group III-V) compared to before treatment (D-4) $(\mathrm{p}<0.05)$. No significant difference in the urine protein level was observed on D-4 compared to on D-25 in Group II ( $p>0.05)$ (TABLE 4). 
TABLE 4. Effect of ethanolic extract of S. macrophylla seed on urine protein level (mg/ dL) on diabetic rats

\begin{tabular}{clcc}
\hline \multirow{2}{*}{ Group } & \multirow{2}{*}{ Treatment } & \multicolumn{2}{c}{ Mean \pm Deviation Standard } \\
& & $2.27 \pm 0.62$ & $1.31 \pm 0.13$ \\
\hline I & Aquadest & $8.72 \pm 0.64$ & $8.56 \pm 0.44$ \\
II & STZ + aquadest & $8.31 \pm 0.77$ & $5.23 \pm 0.53$ \\
III & STZ + extract $50 \mathrm{mg}$ & $8.08 \pm 0.47$ & $3.71 \pm 0.42$ \\
IV & STZ + extract $100 \mathrm{mg}$ & $8.22 \pm 0.37$ & $2.56 \pm 0.35$ \\
V & STZ + extract $200 \mathrm{mg}$ & \\
\hline
\end{tabular}

D-4: 4 days after STZ induction; D-25: 21 days after administration of ethanolic extract.

\section{DISCUSSION}

In this study, STZ induction resulted in a significant increase in blood glucose level (Group II-V) compared to the control group (Group I). All rats on Group II-V had the blood glucose level higher than $200 \mathrm{mg} / \mathrm{dL}$ indicating the rats became diabetes. Diabetic Streptozotocin-induced diabetes has been described a useful experimental model to study the activity of antidiabetic agents. ${ }^{18}$ Streptozoocin destroys $\beta$-cells of the pancreas and induces hyperglycemia. ${ }^{11-13,19}$

After administration of ethanolic extract of S. macrophylla seed to the diabetic rats on Group III-V for 21 days, a significant decrease in blood glucose level was observed which was close to the normal level $(<200$ $\mathrm{mg} / \mathrm{dL}$ ). In addition, the antidiabetic effect of the ethanolic extract of $S$. macrophylla seed was in a dose-dependent manner (TABLE 1). The antidiabetic effect of $S$. macropylla seed extract has been previously reported by some authors..$^{9,10,17}$ Its mechanism of action as antidiabetic has been also investigated. Kalaivanan et al..$^{10}$ reported that ethanolic extract of mahogany seed can increase insulin production and stimulate the regeneration of $\beta$-cells of the pancreas. Swietenia macropylla seed extract was also reported can activate the enzyme glucokinase in lowering blood glucose levels. ${ }^{9}$ Moreover, Maiti et al. ${ }^{20}$ and Dewanjee et $a l .{ }^{21}$ have successfully isolated swietenine, a tetranortriterpenoid, from the $S$. macrophylla seeds and have proven its hypoglycemic activity in type 2 diabetic rats.

Serum MDA level of rats four days after STZ induction significantly higher than without STZ induction indicating that oxidative stress developed in diabetic rats after STZ induction. After administration of ethanolic extract of $S$. macrophylla seed to the diabetic rats on Group III-V for 21 days, a significant decrease in serum MDA level was observed (TABLE 2). It indicates that the ethanolic extract of $S$. macrophylla seed is able to correct the diabetes-induced oxidative stress. The ethanol extract of $S$. macrophylla seeds was proven to have antioxidant activity in the streptozotocin-induced diabetic rats. ${ }^{17}$ Furthermore, the antioxidaive compounds from S. macropylla have been isolated such as swietemacrophyllanin, catechin, and epicatechin. $^{22}$

Serum creatinine and urine protein level of rats four days after STZ induction significantly higher than without STZ induction indicating the decrease of renal function. Diabetes-associated oxidative stress causes glomerular hypertrophy, decrease of glomerular filtration rate and inhibits cell 
Lukman La Basy et al., The effects of the ethanolic extract of mahogany seeds (Swietenia macrophylla King) on the renal function of streptozotocin-induced diabetic rats

proliferation that lead to the decrease of renal function. ${ }^{5-7}$ After administration of ethanolic extract of $S$. macrophylla seed to the diabetic rats on Group III-V for 21 days, a significant decrease in serum creatinine and urine protein levels were observed (TABLE 3 and 4). It clearly demonstrates that the ethanolic extract of $S$. macrophylla seed is able to protect the decrease of renal function due to the diabetesinduced oxidative stress. As explained by Debasis et al. ${ }^{9}$, the renal protective effect of the extract of $S$. macrophylla seed may be explained by two ways. One way may be due to the insulinotrophic effect of this extract that results correction in blood glucose level that prevents the ROS generation by preventing glucose autooxidant and by glication. Another way may be the presence of antioxidative compounds in this extract that lowered the levels of end products of free radicals like MDA.

\section{CONCLUSION}

In conclusion, the ethanolic extract of mahogany seed (S. macropylla King) is able to correct renal dysfunction of streptozotocininduced diabetic rats as indicated by the decrease of serum creatinine and urine protein after administration of this extract. The renal protective effect of the ethanolic extract of mahogany seed may be due to its antidiabetic and antioxidant effects.

\section{ACKNOWLEDGEMENTS}

We would like to express our gratitude to Mr. Suparno (Technician of the Laboratory of Physiology, Faculty of Medicine, UGM) for his relentless support of this research.

\section{REFERENCES}

1. ADA. Diagnosis and clasification of diabetes mellitus. Diabetes Care 2004; 27: S5-S10. http://dx.doi.org/10.2337/diacare.27.2007.S5

2. Fowler MJ. Microvascular and macrovascular complications of diabetes. Clinical Diabetes 2008; 26: 77-82. http://dx.doi.org/10.2337/ diaclin.26.2.77

3. Giacco F, Brownlee M. Oxidaive stress and diabetic complications. J Am Heart Ass 2010; 107: 1058-70.

4. Evans LJ, Goldfine DI, Maddux AB, Grodsky MG. Oxidative stress and stress-activated signaling pathways: a unifying hypothesis of type 2 diabetes. Endocrine Rev 2002; 23(5): 599-622. http://dx.doi.org/10.1210/er.20010039

5. Calabrese V, Mancuso C, Sapienza M, Puleo E, Calafato S, Cornelius $\mathrm{C}$, et al. Oxidative stress and cellular stress response in diabetic nephropathy. Cell Stress Chaperones 2007; 12 (4): 299-306. http://dx.doi.org/10.1379/ CSC-270.1

6. Ozeki M, Nagasu H, Satoh M, Namikoshi T, Haruna T, Tomita N, et al. Reactive oxygen species mediate compensatory glomerular hypertrophy in rat uninephrectomized kidney. J Physiol Sci 2009; 59: 397-404. http://dx.doi. org/10.1007/s12576-009-0048-4

7. Nobrega MA, Fleming S, Roman RJ, Shiozawa M, Schlick N, Lazar J, et al. Initial characterization of a rat model of diabetic nephropathy. J Am Diabetes Ass 2004; 53: 735-42. http://dx.doi.org/10.2337/ diabetes.53.3.735

8. Liang YZ, Xie P, Chan K. Quality control of herbal medicines. J Chromatogr B Analyt Technol Biomed Life Sci 2004; 812 (1-2): 5370.

http://dx.doi.org/10.1016/S15700232(04)00676-2 
9. Debasis D, Kausik C, Kazi AL, Bera KT, Ghosh D. Antidiabeteic potential of the aqueous-methanolic extract of seed of Swietenia mahagoni (L) Jacq. in streptozotocin-induced diabetic male albino rat: a correlative and evidance-based approach with antioxidative and antihyperlipidemic activities. JEBCAM 2011; DOI: http://dx.doi. org/10.1155/2011/892807.

10. Kalaivanan K, Pugalendi KV. Antihyperglycemic effect of the alcoholic seed extract of Swietenia macrophylla on streptozotocindiabetic rats. Pharmacognosy Res 2011; 3(1): 76-71.

11. Ha TS, Choi JY, Park HY, Lee JS. Gingseng total saponin improves producyte hypermeability induced by high glucose and advanced glycosylation endproducts. J Korean Med Sci 2011; 26: 1316-21. http:// dx.doi.org/10.3346/jkms.2011.26.10.1316

12. Szkudelski, T. The mechanism of alloxan and streptozotocin action in $\beta$ cell of the rat pancreas. Physiol Res 2001; 50: 536-46.

13. Abeeleh AM, Ismail BZ, Alzaben RK, AbuHalaweh AS, Al-Essa K.M, Abuabeeleh J, et al. Induction of diabetes mellitus in rats using intraperitonial streptozotocin: a comparation between 2 strains of rats. Eur J Sci Res 2009; 32 (3): 398-402.

14. Trinder P. Quantitative determination of glucose using GOP-PAP method. Clin Biochem 1969;6:24-5. http://dx.doi. org $/ 10.1177 / 000456326900600108$

15. Coresh J, Astor BC, McQuillan G, Kusek J, Greene T, Van Lente F, et al. Calibration and random variation of the serum creatinine assay as critical elements of using equations to estimate glomerular filtration rate. Am J Kidney Dis 2002; 39(5):920-9. http://dx.doi. org/10.1053/ajkd.2002.32765

16. Janero DR. Malondialdehyde and thiobarbituric acid-reactivity as diagnostic indices of lipid peroxidation and peroxidative tissue injury. Free Radic Biol Med 1990; 9 (6): 515-40. http://dx.doi.org/10.1016/0891-5849 (90)90131-2

17. Kalpana K \& Pugalendi KV. Antioxidative and hypolipidemic efficacy of alcoholic seed extract of Swietenia macrophylla in streptozotocin diabetic rats. J Basic Clin Pysiol Pharmacol 2011; 22(1-2):11-21. http:// dx.doi.org/10.1515/jbcpp.2011.001

18. Gajdosik A, Gajdosikova A, Stefek M, Navarova J, Hozova R. Streptozotocininduced experimental diabetes in male Wistar rats. Gen Physiol Biophys 1999; 18:54-62.

19. Szkudelski T. The mechanism of alloxan and streptozotocin action in B cells of the rat pancreas. Physiol Res 2001; 50: 536-46.

20. Maiti A, Dewanjee S, Sahu R. Isolation of hypoglycemic phytoconstituent from Swietenia macrophylla seeds. Phytother Res 2009; 23(12): 1731-3. http://dx.doi. org/10.1002/ptr.2821

21. Dewanjee S, Miti A, Das K, Mandal SC, Dey SP. Swietenine: a potential oral hypoglycemic from Swietenia macrophylla seed. Fitoterapia 2009; 80(4):249-51. DOI: 10.1016/j. fitote.2009.02.004.

22. Falah S, Suzuku T, Katayama T. Chemical constituents from Swietenia macrophylla bark and their antioxidant activity. Pak J Biol Sci 2008; 11(16):2007-12. 